This is a paper published in ECOLOGICAL APPLICATIONS. This paper has been peer-reviewed and includes the final publisher proofcorrections and journal pagination.

Citation for the published paper:

Andersson, E., Barthel, S. and Ahrné, K. (2007) Measuring social ecological dynamics behind the generation of ecosystem services.

Ecological applications. Volume: 17 Number: 5, pp 1267-1278. http://www.esajournals.org/doi/abs/10.1890/06-1116.1

Access to the published version may require journal subscription. Published with permission from: Ecological Society of America.

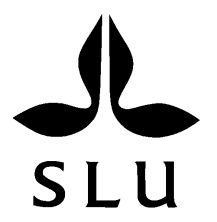

Epsilon Open Archive http://epsilon.slu.se 


\title{
MEASURING SOCIAL-ECOLOGICAL DYNAMICS BEHIND THE GENERATION OF ECOSYSTEM SERVICES
}

\author{
E. Andersson, ${ }^{1,3}$ S. Barthel, ${ }^{1}$ AND K. Ahrné ${ }^{2}$ \\ ${ }^{1}$ Department of Systems Ecology, Stockholm University, Svante Arrhenius väg 21 A, 10691 Stockholm, Sweden \\ ${ }^{2}$ Department of Entomology, Swedish University of Agricultural Sciences, Ulls väg 16, Box 7044, 75007 Uppsala, Sweden
}

\begin{abstract}
The generation of ecosystem services depends on both social and ecological features. Here we focus on management, its ecological consequences, and social drivers. Our approach combined (1) quantitative surveys of local species diversity and abundance of three functional groups of ecosystem service providers (pollinators, seed dispersers, and insectivores) with (2) qualitative studies of local management practices connected to these services and their underlying social mechanisms, i.e., institutions, local ecological knowledge, and a sense of place. It focused on the ecology of three types of green areas (allotment gardens, cemeteries, and city parks) in the city of Stockholm, Sweden. These are superficially similar but differ considerably in their management. Effects of the different practices could be seen in the three functional groups, primarily as a higher abundance of pollinators in the informally managed allotment gardens and as differences in the composition of seed dispersers and insectivores. Thus, informal management, which is normally disregarded by planning authorities, is important for ecosystem services in the urban landscape. Furthermore, we suggest that informal management has an important secondary function: It may be crucial during periods of instability and change as it is argued to promote qualities with potential for adaptation. Allotment gardeners seem to be the most motivated managers, something that is reflected in their deeper knowledge and can be explained by a sense of place and management institutions. We propose that co-management would be one possible way to infuse the same positive qualities into all management and that improved information exchange between managers would be one further step toward ecologically functional urban landscapes.
\end{abstract}

Key words: ecosystem services; functional groups; institutions; local ecological knowledge; management; sense of place; urban ecology.

\section{INTRODUCTION}

Social and ecological systems are interlinked and their separation is arbitrary when analyzing sustainable use of natural resources (Berkes and Folke 1998). The linkages between management and ecological processes have often been approached qualitatively, but very few, if any, studies actually quantify effects of ecosystem management on the generation of ecosystem services, which we do in this article. While the relationship between social features and ecosystem services could be studied in any social-ecological system, we have chosen urban green areas because cities have qualities that make them especially interesting, e.g., the human dominance and profound importance of human activities (e.g., Collins et al. 2000, Grimm et al. 2000). The aim of this article was to determine whether superficially similar urban green areas can be treated as uniform or if management matters. Further, the links between institutions, local ecological knowledge, and management practices and their connection to the delivery of three ecosystem services is analyzed.

Manuscript received 29 June 2006; revised 26 January 2007; accepted 7 February 2007. Corresponding Editor: J. A. Powell.

${ }_{3}^{3}$ E-mail: erik.andersson@ecology.su.se
About half of Earth's human population today lives in cities, and the proportion is increasing (United Nations 2005). This generates a tremendous pressure to develop urban green areas for alternative land-uses. However, there are strong arguments for their preservation: Urban green areas generate many ecosystem services that contribute to human well-being (Daily 1997, Chiesura 2004) and provide habitat for many organisms (see, e.g., Saure 1996, Tommasi et al. 2004). These services could also potentially help mitigate the growing disconnection of urban residents from nature (Pyle 1978, 1993). Cities today influence the use of natural resources globally (Folke et al. 1997, Alberti et al. 2003), and to gain the much needed, broad-based public support for a sustainable use of ecosystems, inside and outside cities, the places where people live and work need to offer opportunities for meaningful interactions with functioning ecosystems (Miller 2005).

We focused on three types of green areas in the urban landscape of Stockholm, Sweden: cemeteries, city parks, and allotment gardens. These three types of green areas were chosen as they are well-defined green, open spaces of comparable age and size while clearly different in their organization. City parks are included in urban green plans, while the other two are not. Cemeteries are usually owned by the Church of Sweden, and most city 
TABLE 1. The sizes and approximate dates of establishment for the 12 study sites in Stockholm, Sweden, and impervious surface (IS) within a $300-\mathrm{m}$ radius.

\begin{tabular}{lccc}
\hline \hline Study site & Size (ha) & Date established & IS (\%) \\
\hline Allotment garden 1 & 1.56 & 1917 & 39.9 \\
Allotment garden 2 & 5 & 1905 & 39.2 \\
Allotment garden 3 & 2.5 & 1954 & 11.2 \\
Allotment garden 4 & 6.46 & 1915 & 17.2 \\
Cemetery 1 & 5.3 & late 19th century & 19.8 \\
Cemetery 2 & 2.41 & $\sim 1780$ & 20.5 \\
Cemetery 3 & 9 & 1920 & 26.5 \\
Cemetery 4 & 5.7 & 15th century & 76.1 \\
City park 1 & 9.37 & 1936 & 34.3 \\
City park 2 & 4 & 1840 & 65.0 \\
City park 3 & 5.18 & $\sim 1880-1930$ & 54.8 \\
City park 4 & 11 & 17th century & 37.9 \\
\hline
\end{tabular}

parks are owned by the government, while allotment gardens are areas reserved for horticulture where plots of land are leased to individuals. Cemeteries and parks are managed by salaried managers, often alone, while allotment gardeners are organized in associations, with elected chairmen and committees. Individual allotment gardeners share obligations and regulations for the management of the whole area, but manage their own plots relatively independently and on a voluntary basis.

Management practices are partly constrained or enabled by social institutions and by the level of local ecological knowledge (LEK; Berkes and Folke 1998, Berkes et al. 2000). LEK is used here as knowledge held by an individual or a specific group of people about their local ecosystem, and the concept of institutions is used as the accepted rules and norms adopted by individuals and used within and across organizational settings (Ostrom 2003). It has been suggested that LEK generally is low among urban residents, but can be promoted by factors such as active land management and participation in outdoor recreation (cf. Theodori et al. 1998, McDaniel and Alley 2005). Sense of place is defined as an intimate emotional attachment to a place, created through firsthand interaction between humans and places (Kaltenborn 1998, Cantrill and Senacha 2001). Sense of place has been suggested to be a reliable predictor of how people will react to environmental impacts, as those with strong attachment to a place seem more committed to learn about and actively respond to negative change, which, in turn, enhances the emotional bond of these stewards to that place (Kaltenborn 1998, Oreszcyn and Lane 2000, Rogan et al. 2005). Thus, we hypothesized that the differences in organization and the degree of freedom in decision-making between the green areas would lead to differences in the managers' sense of place and willingness to increase their local ecological knowledge and respond to environmental feedback. If this is true, the corollary is that management practices should differ as well.

The ecosystem services were assessed indirectly through surveys of functional groups. The three groups were pollinators (bumble bees), seed dispersers (birds), and insectivores (birds) (see Appendix A). They contribute, respectively, to the ecosystem services of pollination (Corbet et al. 1991, Buchmann and Nabhan 1996), seed dispersal (e.g., Robinson and Handel 1993, Sekercioglu et al. 2004), and pest regulation (e.g., Franz 1961, Mols and Visser 2002, Sekercioglu et al. 2004, Ellis et al. 2005). Birds and bumble bees are easily surveyed and are also organisms that most managers recognize and have some kind of emotional connection to.

Specifically, we tried to connect these different areas of research by addressing three questions: (1) To what extent do different management practices in the three types of urban green areas result in different patterns of species richness and abundance? (2) What are the possible links between urban species diversity patterns and ecological functions? (3) Are differences in management practices linked to the local social-ecological context of institutions, LEK, and sense of place?

\section{Study Area}

The study used allotment gardens, cemeteries, and city parks within Stockholm County, Sweden. This is the most densely populated area in Sweden, with $>2870$ inhabitants $/ \mathrm{km}^{2}$ (SCB 2005), and a total population of 1.8 million people. Regional plans for green areas focus on 10 green wedges and transverse green corridors that are meant to constitute Stockholm's most important green areas. Parks are included in green planning and make up more than 1/10 of Stockholm Municipality's total (SCB 2005). There are also many other green areas, among them 10000 allotment gardens occupying 210 ha of land and involving about 24000 people (Björkman 2000, Moberg 2003, Nolin 2003). Many of them are located outside the wedges and corridors and thus not included in green planning. Allotment gardens in Stockholm are well-managed flower-rich areas differing in size (3450-70000 $\mathrm{m}^{2}$ ) and spatial organization, from proper cultivation plots to more gardenlike plots with small houses and lawns. Cemeteries are another overlooked category of green areas, and cover $\sim 250$ ha. We chose four sites from each of the three categories as study sites (Table 1). The areas were chosen according to two criteria: age (older than 50 years) and size (approximately within 1-10 ha). Percentage of impervious surface (IS) within a 300-m radius from the study sites was measured as an indication of landscape context.

\section{Methods \\ Pilot study}

The study started with a pilot study (cf. Patton 2002) of allotment gardens during spring 2003. The aim was to decide on how to bring together the different research fields into one study and to gather primary information about management practices, social institutions, ecological features in allotments, and finally, to outline the survey methods. The evaluation included 11 test interviews with randomly chosen allotment holders 
and field observations in eight sites managed by allotment associations.

\section{Quantitative data}

We used species diversity and abundance of birds and bumble bees as indicators of ecosystem services. The species abundance and composition within a functional group are indirect measures of the performance of the ecosystem service, as they determine the efficiency of the ecological functions on which the ecosystem services are based (Chapin et al. 1997, 1998, Norberg 1999, Rosenfeld 2002, Kremen 2005). Information about bird diets comes from Cramp (1977-1994).

Bird surveys. - We collected data on the relative abundance of individual bird species at 12 point count locations, one in each of the study sites. Point locations were sampled four times during 2005, two times during winter and two times during the breeding season, all in the morning. We used a three-banded fixed-radius methodology, with the bands $0-25 \mathrm{~m}, 25-50 \mathrm{~m}$, and $>50 \mathrm{~m}$, and a count duration of $5 \times 2$ minutes (Gregory et al. 2004). All birds seen or heard were recorded, except those flying over the station as it was uncertain whether they used the area or not. Birds were categorized in functional groups according to their diet, and only the assemblages of seed dispersers (either hoarding granivores or frugivores) and insectivores were analyzed.

Bumble bee surveys.-Daylight surveys of bumble bees were conducted in May, June, and July during good weather. At each site, between 9 and 14 evenly distributed, $3 \times 3 \mathrm{~m}$ quadrats placed to contain species in flower were established. All bumble bees entering the quadrat during a 5 -minute survey period (10 minutes in July) were identified to species according to Løken (1973), and the plant species visited recorded. Bumble bees were surveyed while foraging and the green areas' suitability as nesting sites was not assessed.

Ecological data analysis.-Since the number of samples and the number of bumble bee individuals observed differed among sites, an individual-based rarefaction was done with EcoSim 7.71 (Gotelli and Entsminger 2006). Individual-based rarefaction uses probability theory and the information provided by the collected species to estimate the mean species richness (Magurran 2004). Data from all sites were rarefied to 26 individuals, and the resulting estimate of species richness was used in the diversity analysis. Data on pollinator abundance was log-transformed before the analysis. Differences and/or similarities in community structure between the three types of green areas were described using non-metrical multidimensional scaling ordination (MDS; Clarke 1993). Differences were tested statistically using one-way analysis of similarities (ANOSIM) randomization test (Clarke 1988). Data was analyzed in two ways: either untransformed, using the relative abundances of different species, or presenceabsence transformed to analyze the species assemblages.
Differences in species richness and abundance within each functional group, between sites, were analyzed using one-way ANOVA.

\section{Qualitative data}

The purpose with the qualitative approach (Kvale 1997, Patton 2002) was to analyze social features in relation to the three ecosystem services. The social features included management practices, institutions, local ecological knowledge, and sense of place held by managers and gardeners toward their respective areas. We used multiple forms of data in our methodological design: the pilot study, a survey, and semi-structured interviews. Only semi-structured interviews were used in cemeteries and parks.

Survey.-In 2004 and 2005, a questionnaire was sent out to all gardeners in four allotment associations, which made 532 respondents in total. The objective was to get information about management practices and local institutions and to identify key informants (people held to be especially knowledgeable about gardening and the local ecosystem [cf. Davis and Wagner 2003]) for the interview study. The purpose with identifying key informants for semi-structured interviews was to extract maximum information from a minimum of respondents (Patton 2002). More than two-thirds $(68 \%)$ of the allotment holders responded (anonymously) to the questionnaire.

Semi-structured interviews.-Twenty-six semi-structured interviews were carried out. Fifteen were conducted with key allotment holders, as identified by the questionnaire, five with head managers of cemeteries, and four with managers of city parks. In addition, the head city gardener of Stockholm was interviewed for further information about her relationship with the interviewed park managers. The purpose of the interviews was to understand interviewee's (1) local ecological knowledge; (2) to identify key management practices and social institutions that have important implications for ecosystem dynamics, even if the linkages between these social features and ecosystem dynamics possibly was unknown to the respondents; and (3) to assess the emotional bond of the respondents to the area. Written questions (see Appendix C) were used as a guideline. These questions were open-ended (Kvale 1997), with the possibility to follow up clues that were revealed.

All interviews were recorded and transcribed; the length of the interviews varied between 60 and 90 minutes. The transcribed interviews were analyzed by classifying respondents' answers in relation to the topics of local ecological knowledge, of institutions, of practices, and of sense of place. Evaluation of local ecological knowledge was made by analyses of the respondents' answers to questions regarding site-specific abiotic conditions, interplay between organisms and these conditions, and interactions between organisms on multiple scales. The answers were compared to the scientific understanding of ecosystem dynamics in 
TABLE 2. Average dissimilarities (Bray-Curtis) within each functional group between the different categories of green areas.

\begin{tabular}{lccc}
\hline \hline $\begin{array}{c}\text { Functional } \\
\text { group }\end{array}$ & $\begin{array}{c}\text { City parks- } \\
\text { cemeteries }\end{array}$ & $\begin{array}{c}\text { City parks- } \\
\text { allotment gardens }\end{array}$ & $\begin{array}{c}\text { Allotment } \\
\text { gardens-cemeteries }\end{array}$ \\
\hline Insectivores & 51.44 & 64.10 & 45.44 \\
Seed dispersers & 53.25 & 67.12 & 52.64 \\
Bumble bees & 30.23 & 35.49 & 32.38 \\
\hline
\end{tabular}

cultural landscapes. The sense of place held by the respondents colored the answers and when emotions in relation to the area were revealed, they were followed up with additional questions.

Results: Inventories of Functional Groups, Management Practices, and the Social Mechanisms BEHIND THEM

Allotment gardens had a much higher abundance of bumble bees than the two other types of green areas, and differences in community structure were found for seed dispersers and insectivores, which might be important if the functional groups were broken up in more detail. Diversity indices showed no differences between the different types of green areas. Management practices in allotment gardens clearly benefit bumble bees, and the difference between the areas seem to increase the total number of species, at least for insectivores. We identified 10 management practices of potential importance used among managers (see Table 3). Social mechanisms that structure management practices differ considerably between the three classes, evidenced by different types of protective norms, strength of emotional ties, and level of local ecological knowledge (see Table 4).

\section{Inventories of functional groups}

Bird communities and species assemblages.-No significant differences were found in species composition (species present; global $R=0.15, P=0.124$ ) or community structure (relative abundance of the different species; global $R=0.148, P=0.097$ ) between the three different types of green areas during winter. The community structure did, however, change with the type of green area during the breeding season (Table 2). The insectivore community structure differed between the three categories of green areas (global $R=0.523, P=$ 0.003 ). However, only allotment gardens and city parks differed significantly in the pairwise test (pairwise $R=$ 0.813, $P=0.029$ ). The species composition revealed another pattern: Only allotment gardens and cemeteries differed significantly (pairwise $R=0.344, P=0.029$ ). Based on the number of individuals of different species, the composition of seed dispersers differed between the three categories of green areas (global $R=0.332, P=$ 0.012). Again, only allotment gardens and city parks differed significantly in the pairwise test (pairwise $R=$ $0.62, P=0.029$ ). The species composition itself showed no significant differences in the pairwise test (pairwise
$R=0.182-0.38, P=0.057-0.143)$. No statistically significant differences were found between sites for the species richness within either functional group.

Bumble bee communities and species assemblages.-In total, 755 bumble bee individuals from 14 different species were observed (Appendix A). Total number of species observed was higher in allotment gardens than in parks or cemeteries, but not significantly so. However, four species (Bombus sylvarum, B. subterraneus, B. ruderarius, and $B$. norvegicus) were only observed in allotment gardens. When the variation in number of bumble bee individuals observed was taken into account, we found no difference in species diversity between cemeteries, city parks, and allotment gardens (Kruskal-Wallis $H=0.50, P=0.779$ ) and there was no difference between bumble bee communities (global $R=$ 0.088, $P=0.229$ ) (Table 2). However, bumble bee abundance differed significantly between the three types of green areas (Fig. 1). Among the parameters measured, percent coverage of flowering plants was the one explaining most of the variation in bumble bee abundance ( $n=12, r=0.88$; Fig. 2$)$. These results were most influenced by the three most common species, Bombus lapidarius, B. terrestris, and B. pascuorum. When those three species were analyzed separately, they showed the same pattern as the total species assemblage. The other species observed were too uncommon to include in any meaningful single-species analysis.

\section{Management practices}

In order to compare areas and evaluate the management, we divided the effects of the practices into two types: protection and habitat improvement. Protection was further subdivided into total protection or protection of vulnerable life stages, and habitat improvement into food supply, structural complexity, soil quality, maintained or increased plant diversity, and well-being (Table 3). The quotes in the text reflect general perceptions within the different groups of managers.

Management practices linked to seed dispersal and pest control.-One example of specific practices that may affect the abundance and diversity of insectivorous birds was that $93 \%$ of the allotment gardeners (Survey A-D; all respondents and surveys can be found in Appendix B), all cemeteries, and all city parks (respondents 16-25) prohibit the use of pesticides. Managers in cemeteries and allotment gardens (27\%; Survey A-D) provided birds with food, birdbaths, and nesting boxes. In 


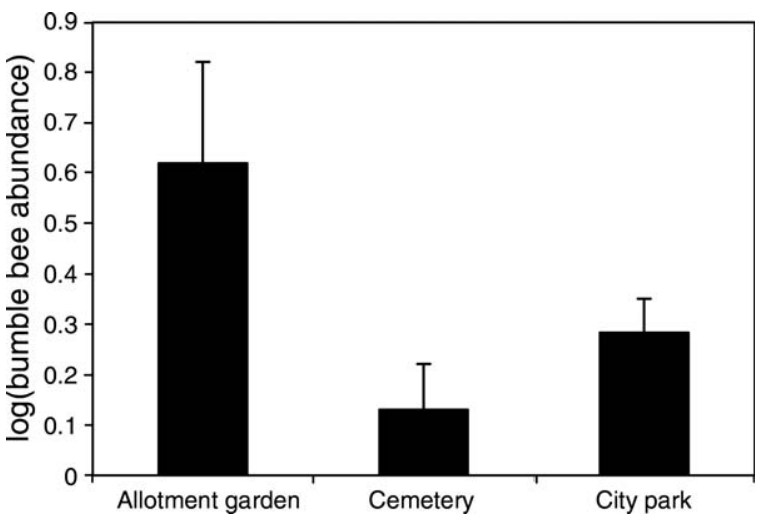

FIG. 1. Bumble bee abundance was significantly higher in allotment gardens than in both cemeteries and parks. There was no significant difference between parks and cemeteries. Error bars represent $95 \%$ confidence intervals.

allotments and cemeteries, care was also taken to protect small birds during vulnerable life stages, e.g., by preserving bird nests when trimming hedges (see Table 3). Winter-feeding was performed by $28 \%$ of the allotment holders (Survey 2004 and 2005) and, to some extent, in the cemeteries. The main targets were small birds, such as Blue Tit (Parus caerulescens) and Great Tit (Parus major), but this practice also favors other birds such as the Eurasian Nuthatch (Sitta europaea). One practice that seemed to be exclusively performed in allotment gardens was tilling of the soil, i.e., turning horse manure and dead plants into the soil, during early fall. Management practices that protect small birds or enhance their habitat seemed largely absent in city parks. The interviews with the park managers (Respondents 16-19) did reveal, however, that some practices such as winter feeding and, in one case, even putting up nesting boxes, were performed by visitors in some parks.

Management practices linked to pollination.-Managers, especially in allotment gardens, employed several practices that may affect living conditions for pollinating insects. The allotment gardeners' desire to have colorful flowers did increase the flower richness and the length of the flowering period, and many allotment gardeners $(45 \%)$ intentionally plant flowers with the sole intent to attract pollinators. Salix spp., an important food source for early-flying bumble bee species, was also allowed to grow in the areas. Other practices linked to crucial life stages of bumble bees included provision and active protection of nests (Respondents 11 and 15). Practices linked to pollinating insects were found to be rare in cemeteries and city parks. Cemeteries had a higher total number of flowering plant species than parks, but there was no difference in mean coverage of flowering plant species $(P=0.31)$. The interviews further revealed that managers in cemeteries increase flower richness for prolonged periods compared to city parks in general, but they did not actively choose plants that attract pollinators (Respondents 21-26). Some of the interviewed park managers did, on the other hand, plant flowerbeds with the sole aim of attracting butterflies (Respondents 16-19), even if these were very limited in size relative to the whole park.

Sense of place, local ecological knowledge, and institutions. - Allotment gardens can be seen as common pool resource systems (sensu Ostrom 1990), except for one important aspect: Allotment gardeners are not economically dependent on their garden plots. Instead, the most important driver for action seemed to be the sense of place, and all interviews reflected a strong emotional bond to their plots and the surrounding garden area (Respondents 1-15). The park managers were perhaps better described as planners; they interpreted the green plans and employed private enterprises to do the actual management. Compared to allotment gardens and cemeteries, where institutions were quite homogeneous, institutions structuring management of city parks in Stockholm showed large individual differences. These were partly ascribed to the different histories of the parks (Respondents 16-19). The relative strength of sense of place, LEK, and protective norms among different managers are shown in Fig. 3.

1. Allotment gardeners' knowledge, institutions, and sense of place.- - It became evident during the interviews how strong the emotional bond between the gardeners and their plots was (Respondents 1-15). This bond was expressed differently; here is one example:

This place is like an oasis for the soul. I get rid of stress and relax when I get here ... it is fantastic to see how they [the plants] can grow during a few months. It is fantastic.

- Respondent 12

Local ecological knowledge in allotment gardens seemed to be based primarily on personal practice and

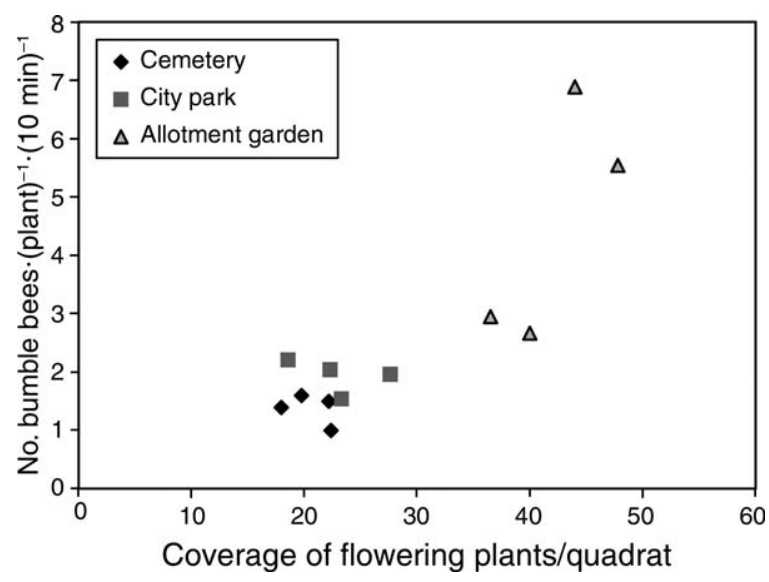

FIG. 2. Bumble bee abundance correlates with coverage of flowering plants. As can be seen, the abundances of flowering plants and bumble bees are significantly higher in allotment gardens. This indicates strong links between management practices in allotments and the ecosystem services of pollination. 
TABLE 3. The table illustrates management practices (P, present; A, absent) in allotment gardens, cemeteries, and city parks of Stockholm and linkages to the ecosystem through their effect on functional groups.

\begin{tabular}{|c|c|c|c|c|c|}
\hline $\begin{array}{l}\text { Management } \\
\text { practices }\end{array}$ & Functional group & Type of effect & $\begin{array}{l}\text { Allotment } \\
\text { gardeners } \\
(n=378)\end{array}$ & $\begin{array}{c}\text { Cemetery } \\
\text { managers } \\
(n=4)\end{array}$ & $\begin{array}{c}\text { City park } \\
\text { managers } \\
(n=4)\end{array}$ \\
\hline Composting & $\begin{array}{l}\text { decomposers, } \\
\text { insectivorous birds }\end{array}$ & food supply, soil quality & $\mathrm{P}(68 \%)$ & $\mathrm{P}(25 \%) \dagger$ & $\mathrm{A}$ \\
\hline Winter feeding of birds & $\begin{array}{l}\text { insectivores, herbivores, } \\
\text { seed dispersers }\end{array}$ & food supply & $\mathrm{P}(28 \%)$ & $\mathrm{P}(50 \%) \dagger$ & A \\
\hline $\begin{array}{l}\text { Enhancing habitats for } \\
\text { small birds }\end{array}$ & $\begin{array}{l}\text { insectivores, herbivores, } \\
\text { seed dispersers }\end{array}$ & $\begin{array}{l}\text { protection of vulnerable } \\
\text { life stages, well-being }\end{array}$ & $\mathrm{P}(27 \%)$ & $\mathrm{P}(75 \%) \dagger$ & A \\
\hline Autumn soil digging & insectivores & food supply & $\mathrm{P}(?) \dagger$ & $\mathrm{P}$ & A \\
\hline Beekeeping & pollinators & $\begin{array}{l}\text { protection of vulnerable } \\
\text { life stages }\end{array}$ & $\mathrm{P}(?) \dagger$ & $\mathrm{P}(25 \%) \dagger$ & A \\
\hline Organic gardening & $\begin{array}{l}\text { decomposers, } \\
\text { insectivorous birds }\end{array}$ & food supply, soil quality & $\mathrm{P}(93 \%)$ & $\mathrm{P}(100 \%) \dagger$ & $\mathrm{P}(100 \%) \dagger$ \\
\hline $\begin{array}{l}\text { Enhancing pollinator } \\
\text { habitats }\end{array}$ & pollinators & $\begin{array}{l}\text { protection of vulnerable } \\
\text { life stages, food supply }\end{array}$ & $\mathrm{P}(45 \%)$ & A & $\mathrm{P}(50 \%) \dagger$ \\
\hline $\begin{array}{l}\text { Active protection of } \\
\text { natural enemies of } \\
\text { pests (except birds) }\end{array}$ & predators of pests & $\begin{array}{l}\text { total protection of certain } \\
\text { species }\end{array}$ & $\mathrm{P}(?) \dagger$ & $\mathrm{P}(50 \%) \dagger$ & A \\
\hline $\begin{array}{l}\text { Prolonged flowering } \\
\text { season }\end{array}$ & pollinators & food supply & $\mathrm{P}(?) \dagger$ & $\mathrm{P}(100 \%) \dagger$ & A \\
\hline $\begin{array}{l}\text { Active choice of plant } \\
\text { species attractive to } \\
\text { pollinators }\end{array}$ & pollinators & $\begin{array}{l}\text { maintained/improved } \\
\text { plant diversity }\end{array}$ & P $(91 \%)$ & A & A \\
\hline
\end{tabular}

Notes: The values in parentheses indicate the percentage of respondents who perform the different management practices; a question mark indicates that the management practice was not included in the questionnaire, but was identified during interviews or from field observations. The sample sizes $(n)$ reported in the column headings represent the numbers of respondents. For sources see Appendix B.

$\dagger$ Not included in questionnaire, but identified during interviews or field observations.

experience or that of fellow gardeners. Science-based knowledge was also present, as some use books and web pages of botanical gardens to gather knowledge (Respondents 1-15 and Survey A-D). The respondents had extensive knowledge of site-specific ecological processes (Table 4). Institutions and organizational aspects that constrain garden management in allotment gardens were the same for different areas, regardless of where in the city they are located. In Stockholm, local allotment associations often rent the land from the landowners for 25-year periods and are thus considered to be proprietors (cf. Ostrom and Schlager 1996). The associations have the right to exclude outsiders from their garden plots, but not to sell the land. They themselves decide on how to organize the management of the allotment gardens, and often it is the allotment associations themselves that enforce their own institutions (Respondents 1-15). The institutions were experi- enced as intolerant by some gardeners, and all respondents shared experiences of plot holders being excluded from the associations.

About the gardening rules, it is the board of this association that sets them. Once a year the board surveys all garden plots and if rules have been broken, the garden holder may ultimately be thrown out.

- Respondent 7

Plants could be chosen freely, with the exception of a few plants that were prohibited by the associations. However, there were norms that urge garden holders to grow vegetables, fruits, berries, and traditional flowers (e.g., Respondents 6, 9, 12, and 13). These norms were evident since $91 \%$ of the gardeners felt that their neighbors wanted them to act in accordance with the norms. (Survey A-D, Appendix B). Other examples

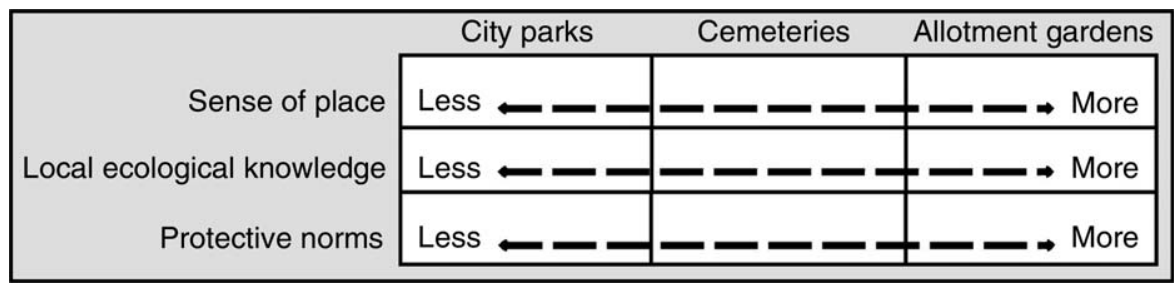

FIG. 3. The relative strength of sense of place, local ecological knowledge, and protective norms among the managers of different green areas in an urban setting. 
TABLE 4. Examples of aspects of local ecological knowledge.

\begin{tabular}{|c|c|c|c|}
\hline Knowledge about: & Allotment gardens & Cemeteries & City parks \\
\hline $\begin{array}{l}\text { Interactions between } \\
\text { organisms }\end{array}$ & $\begin{array}{l}\text { various predator-prey } \\
\text { processes; pollinator- } \\
\text { plant processes; } \\
\text { competition processes; } \\
\text { parasite-transmitter-host } \\
\text { processes; critical life- } \\
\text { stage processes }\end{array}$ & $\begin{array}{l}\text { predator-prey processes; } \\
\text { pollinator-plant } \\
\text { processes; species as } \\
\text { habitats to other } \\
\text { species }\end{array}$ & $\begin{array}{l}\text { parasite-transmitter-host } \\
\text { processes; pollinator- } \\
\text { plant processes; species as } \\
\text { habitats to other species }\end{array}$ \\
\hline $\begin{array}{l}\text { Interplay between organisms } \\
\text { and site specific abiotic } \\
\text { conditions }\end{array}$ & $\begin{array}{l}\text { crop rotation for enhanced } \\
\text { harvest, avoiding disease, } \\
\text { and fertilizing the soil; } \\
\text { using decomposers as } \\
\text { indicators of soil health } \\
\text { and fertility; increasing } \\
\text { microclimate for } \\
\text { decomposers; interaction } \\
\text { between microclimate and } \\
\text { organisms }\end{array}$ & $\begin{array}{l}\text { increasing microclimate for } \\
\text { decomposers }\end{array}$ & \\
\hline Spatial ecological processes & $\begin{array}{l}\text { gardens as important } \\
\text { feeding areas for } \\
\text { pollinators from } \\
\text { surrounding areas; spatial } \\
\text { movements of species }\end{array}$ & & \\
\hline
\end{tabular}

include distinct norms about environmental ethics and protection of pollinator species and small birds (Respondents 1-15). It was also common in allotment gardens to permit growers to keep beehives.

2. Cemetery managers' knowledge, institutions, and sense of place.-Ecological knowledge held by cemetery managers differed somewhat between the studied cemeteries. In general, ecological knowledge was partly based on local experience, but managers held knowledge that was different from the knowledge held by allotment gardeners: It was less comprehensive, as it was oriented more toward small birds and their function as predators of pests and less toward the role of pollinators and seed dispersers. Yet, they seemed to be aware that their cemeteries were relatively rich in flowers, and what that meant for pollinating insects. Cemetery managers expressed no clear sense of place during interviews (Respondent 21-25). Managers were constrained in their daily practices both by written regulations and a multitude of unwritten norms. Management practices were constrained by the funeral law, where the overall goal is successful interments, except for the more parklike sections of cemeteries where management was mainly structured by unwritten norms that seemed to have developed over long time periods (Respondents 21-25). All interviewed cemetery managers expressed the presence of unwritten norms for how to manage these areas. Here is one example of how this was verbalized:

The funeral law is the regulation that we must follow; however, how to manage the green space in between the graves, we pretty much decide ourselves.... There are many unwritten rules that come from the long tradition of funerals.

-Respondent 24
Some cemeteries outside the inner city allowed beehives. Yet, the most obvious social mechanism linked to the studied functional groups was that strict norms of protecting small birds were present in three-quarters of the cemeteries (Respondents 22, 24, and 25).

We leave bird nests intact when we trim the hedges; we'd rather have irregular hedges than hurt the birds, and this is an unwitten rule here.

- Respondent 22

3. City park managers' knowledge, institutions, and sense of place. - City park managers are employed by the city and their ecological knowledge varied greatly between different parks. Some park managers seemed to be quite ignorant of ecological processes in their parks, while others had academic education in ecology. In the latter cases, the kind of knowledge clearly differed from the knowledge in allotment gardens and cemeteries. It was often more general, and there was less knowledge about the linkages between the practices used and ecological processes in the area they manage. All city parks in our case study prohibited pesticides. No indication of sense of place was revealed during the interviews (Respondents 16-20). Head managers of city parks were restricted by physical plans and written regulations developed centrally by the Stockholm Land Administration (Swe. Markkontoret; Respondent 20). This was expressed by a city park manager in the following way:

... our work is determined by a "bible" that we call the agreement. There everything is written down about what actions are to be taken and when.

—Respondent 16 


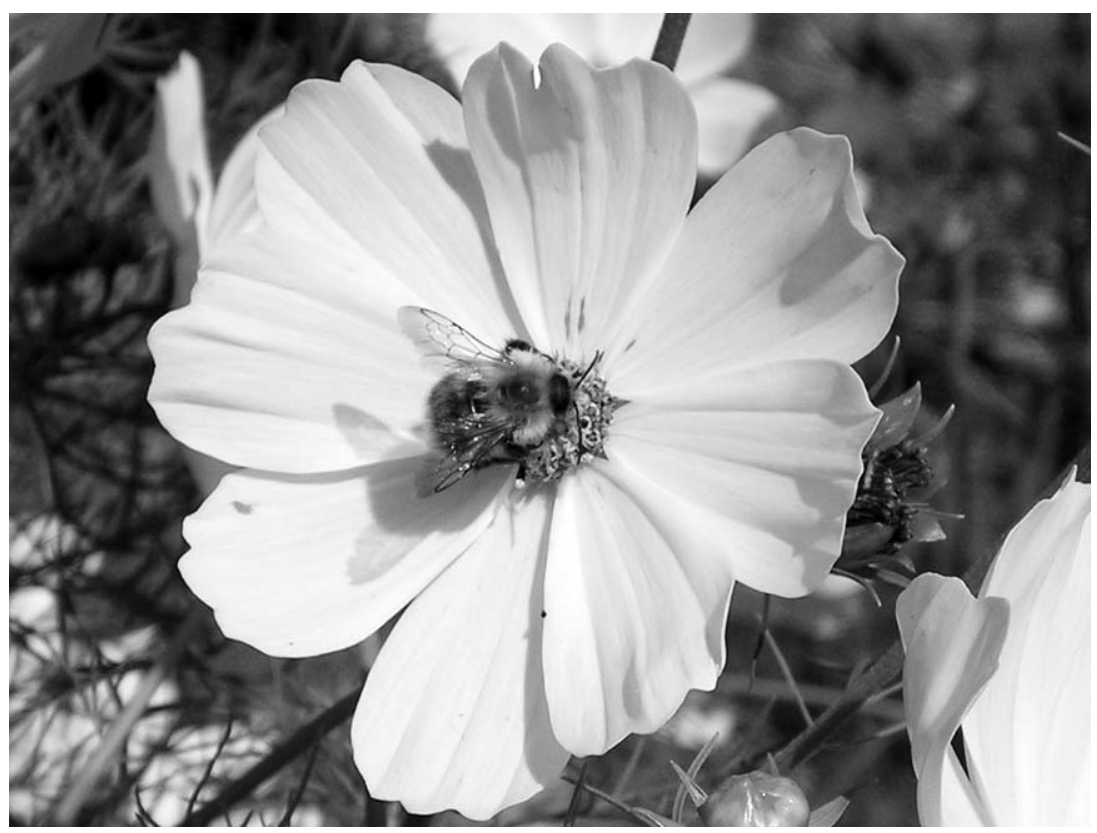

Plate 1. Bumble bees benefit from the management practices used in allotment gardens. Photo credit: S. Barthel.

In some parks, cultural values were the prime concern for their managers, not the biological (Respondents 1620).

\section{DISCUSSION}

\section{Main findings and evaluation}

Green areas such as allotment gardens and cemeteries are often overlooked in green plans developed by the City of Stockholm. However, as this study has shown, they generate important ecosystem services. We have demonstrated a method for examining the linkages between ecosystem services and management practices, institutions, knowledge, and sense of place. Differences in management practices had two consequences that may affect the provision of the different services: differences in the pollinator abundance (see Plate 1) and community structure of seed dispersers and insectivores, both of which set allotment gardens apart from the others.

Interplay between birds and management practices.The two functional groups of birds differed in the relative abundance of different species between the three categories of green areas. Allotment gardens and parks seemed to share much the same seed dispersers but the relative abundance of the different species varied greatly. Most of the difference was made up by the abundance of a few species that were particularly favored in one type of green area, e.g., Turdus pilaris, which thrives in the lawn-dominated parks. We found no significant differences in species representation between the green areas. The pattern for insectivores was somewhat different as both species composition and relative abundance differed between the three types of green areas.
Cemeteries had somewhat different species than parks and allotments, but, as they did not differ from either parks or allotment gardens in community structure, the difference must be created by some of the less-abundant species. Instead, it was parks and allotment gardens that had significantly different relative abundance of different species. The result implies, however, that having different types of green areas increases the total number of insectivore bird species.

The results indicate that local managers, however well informed, have a limited influence over the functional groups of seed dispersers and insect pest regulators within their ambit. Moreover, the knowledge of ecosystem processes working on larger spatial scales seemed very limited (Respondents 1 and 10). As birds are known to respond to landscape as well as local factors (e.g., Hostetler 1999, Melles et al. 2003, Cannon et al. 2005), it might be argued that landscape factors are more important in shaping local species communities for these functional groups. Some of the management practices we had identified as potentially important, e.g., winter-feeding, did not show any effects in our results. As can be seen in Table 3, allotment gardens had the widest range of management practices that offer protection and improved habitat, which supports the hypothesized connection between sense of place and management. Many of these practices were also present in cemeteries, at least to some extent, but for other reasons: Here, institutions seemed to be the main social mechanism behind human interactions with birds. What was lacking in all study sites except one of the parks was management practices and knowledge that increased structural diversity, i.e., favoring many layers of 
vegetation, which is very important for many birds (e.g., MacArthur and MacArthur 1961). The small scale of the studied areas suggests also that their management is most likely to affect small species such as warblers or tits (see, e.g., Hostetler 1999).

Interestingly, the norms protecting small birds in cemeteries and allotments might be linked to ecological processes, or disturbances, that act on longer time scales than those perceived by most gardeners, which are a couple of decades at the most (Respondents 1-15 and 21-25). These norms have some ecological consequences for system functioning during times of stability, as we have shown, but it may be during times of crises, such as pest outbreaks, that they are most ecologically important (Colding and Folke 2001). Thus, it seems that the local managers and their actions have two important functions: First, they influence ecosystem functions during periods of stability, and second, they might be crucial during periods of instability and change.

Interplay between bumble bees and management practices.-Species diversity and species assemblages of bumble bees were rather similar for the three types of green areas despite differences in management practices. Species diversity seemed to be affected by the proportion of green areas within the nearby surrounding landscape. Bumble bees are dependent on continuity of suitable flowering plants as well as good nesting sites within an area limited by their species-specific foraging ranges (Kearns et al. 1998, Osborne et al. 1999, WaltherHellwig and Frankl 2000), which indicate that the landscape context could be of importance.

Bumble bee abundance differed significantly between the three types of green areas, and most of the variation was explained by the variable percent coverage of flowering plants, and to some extent, the number of bumble bee-visited plant species. Other management practices that appeared to be beneficial for pollinators were enhancing pollinator habitats, prolonged flowering season, and active choice of plant species attractive to pollinators; all mainly performed in allotment gardens (see Table 3). Abundance is important since it can affect the efficiency of the ecosystem service (Kremen 2005). Cemetery managers did create flower-rich areas, but seemingly without the intention to attract pollinators, and experienced knowledge about the pollinator-flower interaction seems to be limited. Cemeteries also lacked institutions protecting bumble bees (Respondents 2125). In contrast, allotment gardeners seemed to be well aware of the mutual relationship between pollinators and flowering plants, as well as other ecological processes linked to the pollinator-flower interaction (Respondents 1-15). Such knowledge seemed to originate from the culture of keeping a kitchen garden in the old farming society and have been strengthened during the 100 years of allotment gardening in Stockholm (e.g., Respondents 8, 14, and 15; cf. Lindhagen 1916). In agreement with the quotes and statements from the qualitative interview studies, allotment gardens had significantly more species of bumble bee-visited flowering plants than the two other areas and a significantly higher coverage of flowering plants in the quadrats surveyed. This indicates that in allotment gardens, management practices and their underlying social structures are favorable for the growth of bumble bee populations and of importance if we want to maintain the ecosystem service of pollination within the city. However, some management practices might serve to strengthen services under periods of stability but make the service more vulnerable to disturbance, e.g., beekeeping increases the total abundance of pollinators but may decrease the abundance of native pollinator species (Schaffer et al. 1983, Thompson et al. 2004), which would also have implications for plant communities by favoring honey bee-pollinated flowers.

Methodological evaluation.-The analysis might be weakened by the difficulty of finding replicates within a sufficiently similar landscape context. The surroundings of our study sites differ in the amount of green space vs. impervious surfaces, which makes the elimination of external factors difficult (see Table 1). We limited our study to address within-site conditions and would argue that the three types of green areas are reasonably distinct in terms of content and management. We did, however, discover that the management practices differed considerably within parks and to some degree within cemeteries. Two sites, one cemetery and one park, clearly differed from the others. The cemetery had more in common with the parks and the park had been without active management for the last decades, which had allowed the shrub layer to develop to an extent unequalled by any of the other areas. Our design with four replicates of each category was insufficient to deal with these differences in some of the statistical analyses. Also, a more detailed classification of functional groups might have been better able to capture the effects of different management practices (see, e.g., Rosenfeld 2002).

In the qualitative part of the study, the differences in sense of place, LEK, and, to some degree, even institutions rest on the subjective experiences and perceptions of the respondents, and we realize that our results by no means are exhaustive. One weakness with the interview study was that respondents were chosen differently in allotment gardens, on the one hand, and cemeteries and city parks, on the other. In allotment gardens, we searched for persons knowledgeable about the local social-ecological system, and we identified them in a questionnaire. In city parks and cemeteries, we only interviewed the head managers of the areas, since they make decisions about the management of their respective areas. However, the organizational position of head managers does not always correlate with knowledge about the local social-ecological system. Differences in organization, i.e., one or several managers, also resulted in more material on allotment gardens than cemeteries or parks. We do not see this as a 
problem; rather, as fact and part of the explanation to why we might see differences in management practices between the three types of green areas.

\section{Policy implications for managing ecosystem services in complex systems}

We argue that studies like this are important to inform managers of the indirect effect of management practices primarily aimed at targets other than maintenance of ecosystem services. Awareness of positive side effects may strengthen the institutional foundation for the practices, strengthen the sense of place, and even further increase the probability that the practices will continue over time (Cantrill and Senacha 2001). This is especially important in areas where people are not strongly dependent on local natural resources, since resource dependency has been proposed as one of the strongest drivers behind successful long-term management (see, e.g., Berkes et al. 2003). A close link between practice and planning, here most evident in allotment gardens where the managers do both, has been argued to make adjustments to environmental feedback easier since the managers may detect ecological change more rapidly and have the mandate to adapt management practices accordingly (Berkes 2004). As an example of the opposite case, the management of city parks seem to be less flexible, where bureaucratic procedures must be undertaken before the direction of management can be changed. Allotment gardens, with their numerous managers, offer more opportunities for experimentation and transmission of information, and thus greater potential for more comprehensive knowledge-building than do areas cared for by a sole manager. Many managers make it easier to maintain continuity in the knowledge within the area than if the knowledge is tied to one specific manager and risk being lost if that person leaves. However, our results also indicate that sense of place is restricted to the allotment gardens and the immediate area around them, which implies that they hold a "not in my backyard" mentality (Norton and Hannon 1997).

In our study, only a few interviewees referred to the relationship between different scales (Respondents 1 and 10), but practices performed locally have landscape effects, as bumble bees and birds move outside and between areas, thus extending their services (e.g., Jules and Shahani 2003, Kremen et al. 2004, Bodin et al. 2006). The landscape perspective is, instead, held by the planning authorities. Transfer of knowledge between groups of managers could be helped by creating or making room for an organization bridging, or intermediating the divide (Cash and Moser 2000, Moss and Wissen 2005), with the aim to spark participative learning (Pretty 1995). We argue that the involvement of other stakeholders in the management of cemeteries and especially city parks would promote the same positive features that we found in allotment gardens, i.e., a strong sense of place, ecological knowledge, and continuous learning. Not only would this improve management by getting more motivated managers, it would also increase the different stakeholders' understanding of the ecosystems that provide them with desired services.

Different management objectives create heterogeneity, which is generally held to provide an insurance against uncertainty (e.g., Folke et al. 1996, Loreau et al. 2003). Our data lends at least partial support for the importance of heterogeneity as the species assemblages of insectivores differed between cemeteries and allotment gardens and thus complement each other. Differences in species assemblages may also make the service more stable over time as different species are likely to respond differently to disturbances or changes (Elmqvist et al. 2003).

\section{Conclusions}

The findings in this paper show that relevant knowledge and ecosystem management exist both inside and outside the formal planning, and that different goals, constraints, and motivations create social-ecological systems that differ in their capacity to deliver ecosystem services. We ascribe the differences in management practices to social attributes such as local ecological knowledge, sense of place, and institutions. Data also support the hypothesis that local ecological knowledge correlates positively with sense of place, and our results also show the same pattern for strength and diversity of protective norms and sense of place. All three features are strongest among the informal managers and weakest among employed personnel. Formal managers have less freedom in their decisions, and a larger part of the management objectives are set centrally and change is slow moving. Furthermore, allotment gardens are different from the others in that they have many different managers within each area, something that increases the potential for experimentation and learning.

We believe that communicating the results from studies such as this could help this cooperation by highlighting, for planners and local managers both, the direct and indirect effects of different green-area management. Maintaining different types of green areas contribute to the creation of heterogeneity on a landscape level, which is generally held to increase biodiversity. A move toward participative co-management in cemeteries and, especially, city parks would hopefully promote the same positive features that we found in allotment gardens, i.e., a strong sense of place, ecological knowledge, and continuous learning.

\section{ACKNOWLEDGMENTS}

We thank Carl Folke and Thomas Elmqvist for valuable comments and input on the article and Anna-Sara Liman for practical assistance performing bumble bee surveys. We also thank all the different managers for their time and help. The project was supported by grants from the Swedish Research Council Formas. 


\section{Literature Cited}

Alberti, M., J. M. Marzluff, E. Shulenberger, G. Bradley, C. Ryan, and C. Zumbrunnen. 2003. Integrating humans into ecology: opportunities and challenges for studying urban ecosystems. Bioscience 53:1169-1179.

Berkes, F. 2004. Rethinking community based conservation. Conservation Biology 18:621-630.

Berkes, F., J. Colding, and C. Folke. 2000. Rediscovery of traditional ecological knowledge as adaptive management. Ecological Applications 10:1251-1262.

Berkes, F., J. Colding, and C. Folke, editors. 2003. Navigating social-ecological systems. Building resilience for complexity and change. Cambridge University Press, Cambridge, UK.

Berkes, F., and C. Folke, editors. 1998. Linking social and ecological systems: management practices and social mechanisms for building resilience. Cambridge University Press, Cambridge, UK.

Björkman, L. 2000. Vad betyder koloniträdgårdar för den urbana människan i Stockholm? Länkar mellan fritidsodling i staden, ekologisk kunskap och uthållig samhällsbyggnad. Ph.D. Thesis. Stockholm University, Stockholm, Sweden.

Bodin, Ö., M. Tengö, A. Norman, J. Lundberg, and T. Elmqvist. 2006. The value of small size: loss of forest patches and ecological thresholds in southern Madagascar. Ecological Applications 16:440-451.

Buchmann, S. L., and G. P. Nabhan. 1996. The forgotten pollinators. Island Press, Washington, D.C., USA.

Cannon, A. R., D. E. Chameberlain, M. P. Toms, B. J. Hatchwell, and K. J. Gaston. 2005. Trends in the use of private gardens by wild birds in Great Britain 1995-2002. Journal of Applied Ecology 42:659-671.

Cantrill, J. G., and S. L. Senacha. 2001. Using the "sense of self in place" construct in the context of environmental policymaking and landscape planning. Environmental Science and Policy 4:185-203.

Cash, D. W., and S. C. Moser. 2000. Linking global and local scales: designing dynamic assessment and management processes. Global Environmental Change 10:109-120.

Chapin, F. S., III, et al. 1998. Ecosystem consequences of changing biodiversity: experimental evidence and a research agenda for the future. Bioscience 48:45-52.

Chapin, F. S., III, B. H. Walker, R. J. Hobbs, D. U. Hooper, J. H. Lawton, O. E. Sala, and D. Tilman. 1997. Biotic control over the functioning of ecosystems. Science 277:500-504.

Chiesura, A. 2004. The role of urban parks for the sustainable city. Landscape and Urban Planning 68:129-138.

Clarke, K. R. 1988. Detecting change in benthic community structure. Pages 131-142 in Proceedings, XIVth International Biometric Conference, Namur. Invited papers. Société Adophe Quélét, Gemblous, Belgium.

Clarke, K. R. 1993. Non-parametric multivariate analyses of change in community structure. Australian Journal of Ecology 18:117-143.

Colding, J., and C. Folke. 2001. Social taboos: "Invisible" systems of local resource management and biological conservation. Ecological Applications 11:584-600.

Collins, J. P., A. Kinzig, N. B. Grimm, W. F. Fagan, D. Hope, J. Wu, and E. T. Borer. 2000. A new urban ecologymodeling human communities as integral parts of ecosystems poses special problems for the development and testing of ecological theory. American Scientist 88:416-425.

Corbet, S. A., I. H. Williams, and J. L. Osborne. 1991. Bees and the pollination of crops and wild flowers in the European Community. Bee World 72:47-59.

Cramp, S., editor. 1977-1994. Handbook of the birds of Europe, the Middle East, and North Africa: the birds of the western Palearctic. Oxford University Press, Oxford, UK.

Daily, G. 1997. Nature's services. Island Press, Washington, D.C., USA.
Davis, A., and J. R. Wagner. 2003. Who knows? On the importance of identifying "experts" when researching local ecological knowledge. Human Ecology 31:463-489.

Ellis, J. A., A. D. Walter, J. F. Tooker, M. D. Ginzel, P. F. Reagel, E. S. Lacey, A. B. Bennett, E. M. Grossman, and L. M. Hanks. 2005. Conservation biological control in urban landscapes: Manipulating parasitoids of bagworm (Lepidoptera: Psychidae) with flowering forbs. Biological Control 34: 99-107.

Elmqvist, T., C. Folke, M. Nyström, G. Peterson, J. Bengtsson, B. Walker, and J. Norberg. 2003. Response diversity, ecosystem change, and resilience. Frontiers in Ecology and the Environment 1:488-494.

Folke, C., C. S. Holling, and C. Perrings. 1996. Biological diversity, ecosystems, and the human scale. Ecological Applications 6:1018-1024.

Folke, C., A. Jansson, J. Larsson, and R. Costanza. 1997. Ecosystem appropriation by cities. Ambio 26:167-172.

Franz, J. M. 1961. Biological control of pest insects in Europe. Annual Review of Entomology 6:183-200.

Gotelli, N. J., and G. L. Entsminger. 2006. EcoSim: null models software for ecology. Version 7. Acquired Intelligence and Kesey-Bear. Jericho, Vermont, USA. 〈http://garyentsminger. com/ecosim.htm $\rangle$

Gregory, R. D., D. W. Gibbons, and P. F. Donald. 2004. Bird census and survey techniques. Pages 17-55 in W. J. Sutherland, I. Newton, and R. E. Green, editors. Bird ecology and conservation. A handbook of techniques. Oxford University Press, Oxford, UK.

Grimm, N. B., J. M. Grove, S. T. A. Pickett, and C. L. Redman. 2000. Integrated approaches to long-term studies of urban ecological systems. Bioscience 50:571-584.

Hostetler, M. 1999. Scale, birds, and human decisions: a potential for integrative research in urban ecosystems. Landscape and Urban Planning 45:15-19.

Jules, E. S., and P. Shahani. 2003. A broader ecological context to habitat fragmentation: Why matrix habitat is more important than we thought. Journal of Vegetation Science 14:459-464.

Kaltenborn, B. P. 1998. Effects of sense of place on responses to environmental impacts: A study among residents in Svalbard in the Norwegian high Arctic. Applied Geography 18:169-189.

Kearns, C. A., D. W. Inouye, and N. M. Waser. 1998. Endangered mutualism: the conservation of plant-pollinator interactions. Annual Review of Ecology and Systematics 29: $83-112$.

Kremen, C. 2005. Managing ecosystem services: what do we need to know about their ecology? Ecology Letters 8: 468-479.

Kremen, C., N. M. Williams, R. L. Bugg, J. P. Fay, and R. W. Thorp. 2004. The area requirements of an ecosystem service: crop pollination by native bee communities in California. Ecology Letters 7:1109-1119.

Kvale, S. 1997. Den kvalitativa forskningsintervjun. Studentlitteratur, Lund, Sweden.

Lindhagen, A. 1916. Koloniträdgårdar och planterade gårdar. Rekolid, Stockholm, Sweden.

Løken, A. 1973. Studies on Scandinavian bumble bees (Hymenoptera, Apidae). Norsk entomologisk tidsskrift 20: $1-218$.

Loreau, M., N. Mouquet, and A. Gonzalea. 2003. Biodiversity as spatial insurance in heterogeneous landscapes. Proceedings of the National Academy of Sciences 100:12765-12770.

MacArthur, R. H., and J. W. MacArthur. 1961. On bird species diversity. Ecology 42:594-598.

Magurran, A. E. 2004. Measuring biological diversity. Blackwell Publishing, Oxford, UK.

McDaniel, J., and K. D. Alley. 2005. Connecting local environmental knowledge and land use practices: a human 
ecosystem approach to urbanization in West Georgia. Urban Ecosystems 8:23-38.

Melles, S., S. Glenn, and K. Martin. 2003. Urban bird diversity and landscape complexity: species-environment associations along a multiscale habitat gradient. Conservation Ecology 7(1):5. 〈http:/www.consecol.org/vol7/iss1/art5〉

Miller, J. R. 2005. Biodiversity conservation and the extinction of experience. Trends in Ecology and Evolution 20:430-434.

Moberg, M. 2003. Odlarna på berget-om södra tantolunden. Pages 40-81 in Nordiska museets och Skansens årsbok. 2003. Stadens odlare. Nordiska museets förlag, Värnamo, Sweden.

Mols, C. M. M., and M. E. Visser. 2002. Great tits can reduce caterpillar damage in apple orchards. Journal of Applied Ecology 39:888-899.

Moss, T., and M. Wissen. 2005. Making sense of diversity: a synergy report on an inventory of 113 intermediary organizations of water management in Europe. LeibnizInstitute for Regional Development and Structural Planning, Leibniz, Germany.

Nolin, C. 2003. Koloniträdgårdsrörelsen i Stockholm - dess förutsättingar och uppkomst vid 1900-talets början. Pages 940 in C. Westergren, editor. Stadens odlare. Nordiska museets och Skansens årsbok. Nordiska museets förlag, Värnamo, Sweden.

Norberg, J. 1999. Linking nature's services to ecosystems: some general ecological concepts. Ecological Economics 29: 183-202.

Norton, B. G., and B. Hannon. 1997. Environmental values: a place based theory. Environmental Ethics 19:227-245.

Oreszcyn, S., and A. Lane. 2000. The meaning of hedgerows in the English landscape: different stakeholder perspectives and the implications for future hedge management. Journal of Environmental Management 60:101-118.

Osborne, J. L., S. J. Clark, R. J. Morris, I. H. Williams, J. R. Riley, and A. D. Smith. 1999. A landscape-scale study of bumble bee foraging range and constancy using harmonic radar. Journal of Applied Ecology 36:519-533.

Ostrom, E. 1990. Governing the commons: the evolution of institutions for collective action. Cambridge University Press, Cambridge, Massachusetts, USA.

Ostrom, E. 2003. Doing institutional analysis: digging deeper than markets and hierarchies. Pages $819-848$ in M. Claude and M. Shirley, editors. Handbook of new institutional economics. Kluwer Academic, Dordrecht, The Netherlands.

Ostrom, E., and E. Schlager. 1996. The formation of property rights. Pages 127-156 in S. Hanna, C. Folke, and K.-G. Mäler, editors. Rights to nature. Island Press, Washington, D.C., USA
Patton, M. Q. 2002. Qualitative research and evaluations methods. Third edition. Sage Publications, Thousand Oaks, California, USA.

Pretty, J. N. 1995. Participatory learning for sustainable agriculture. World Development 23:1247-1263.

Pyle, R. M. 1978. The extinction of experience. Horticulture 56: 64-67.

Pyle, R. M. 1993. The thunder tree: lessons from an urban wildland. Beacon Press, Boston, Massachusetts, USA.

Robinson, G. R., and S. N. Handel. 1993. Forest restoration on a closed landfill: rapid addition of new species by bird dispersal. Conservation Biology 7:271-278.

Rogan, R., M. O'Connor, and P. Horwitz. 2005. Nowhere to hide: awareness and perceptions of environmental change, and their influence on relationships with place. Journal of Environmental Psychology 25:147-158.

Rosenfeld, J. S. 2002. Functional redundancy in ecology and conservation. Oikos 98:156-162.

Saure, C. 1996. Urban habitats for bees: the example of the city of Berlin. Pages 47-54 in A. Matheson, S. L. Buchmann, C. O'Toole, P. Westrich, and I. Williams, editors. The conservation of bees. Academic Press, London, UK.

SCB [Statistiska Centralbyrån]. 2005. Statistical yearbook of Sweden. Statistics Sweden, Stockholm and Örebro, Sweden.

Schaffer, W. M., D. W. Zeh, S. L. Buchmann, S. Kleinhans, V. M. Schaffer, and J. Antrim. 1983. Competition for nectar between introduced honey bees and native North American bees and ants. Ecology 64:564-577.

Sekercioglu, C. H., G. C. Daily, and P. R. Ehrlich. 2004. Ecosystem consequences of bird declines. Proceedings of the National Academy of Science 101:18042-18047.

Theodori, G. L., A. E. Luloff, and F. K. Willits. 1998. The association of outdoor recreation and environmental concern: Reexamining the Dunlap-Heffernan thesis. Rural Sociology 63:94-108.

Thompson, K., J. G. Hodgson, R. M. Smith, P. H. Warren, and K. J. Gaston. 2004. Urban domestic gardens (III): composition and diversity of lawn floras. Journal of Vegetation Science 15:373-378.

Tommasi, D., A. Miro, H. A. Higo, and M. L. Winston. 2004. Bee diversity and abundance in an urban setting. Canadian Entomologist 136:851-869.

United Nations. 2005. World population prospects: the 2005 revision. Department of Economic and Social Affairs, Population Division, New York, New York, USA.

Walther-Hellwig, K., and R. Frankl. 2000. Foraging habitats and foraging distances of bumble bees, Bombus spp. (Hym., apidae), in an agricultural landscape. Journal of Applied Entomology-Zeitschrift Fur Angewandte Entomologie 124: 299-306.

\section{APPENDIX A}

Two tables with the bird and bumble bee species found, including functional groups for birds (Ecological Archives A017-048-A1).

\section{APPENDIX B}

A list of interview and survey sources (Ecological Archives A017-048-A2).

\section{APPENDIX C}

The guide for open-ended interviews (Ecological Archives A017-048-A3). 